\title{
Handbook of Florida Water Regulation: Management and Storage of Surface Waters ${ }^{1}$
}

\author{
Michael T. Olexa, Luke D'Isernia, Laura Minton, Dulcy Miller, and Sarah Corbett ${ }^{2}$
}

\section{Preface}

This handbook is designed to provide an accurate, current, and authoritative summary of the principle Federal and Florida laws that directly or indirectly relate to agriculture. This handbook should provide a basic overview of the many rights and responsibilities that farmers and farmland owners have under both Federal and Florida laws as well as the appropriate contact information to obtain more detailed information. However, the reader should be aware that because the laws, administrative rulings, and court decisions on which this handbook is based are subject to constant revision, portions of this publication could become outdated at anytime. Several details of cited laws are also left out due to space limitations.

This handbook is distributed with the understanding that the authors are not engaged in rendering legal or other professional advice, and the information contained herein should not be regarded as a substitute for professional advice. This handbook is not all inclusive in providing information to achieve compliance with the Federal and Florida laws and regulations governing water protection. For these reasons, the use of these materials by any person constitutes an agreement to hold harmless the authors, the Florida Cooperative Extension Service, the Institute of Food and Agricultural Sciences, and the University of Florida for any liability claims, damages, or expenses that may be incurred by any person as a result of reference to or reliance on the information contained in this handbook.

\section{Who Regulates the Management and Storage of Surface Waters?}

In order to prevent harm to Florida's waters, both the water management districts' (WMD) governing boards and the DEP are vested with the authority to require the management and storage of surface water permits (MSSW permits) and impose conditions upon those permits. This authority is delegated almost entirely to the WMDs, which should be consulted before any alteration of surface water is undertaken.

1. This is EDIS document FE605, a publication of the Food and Resource Economics Department, Florida Cooperative Extension Service, Institute of Food and Agricultural Sciences, University of Florida, Gainesville, FL. Published December 2005. Please visit the EDIS website at http://edis.ifas.ufl.edu.

2. Michael T. Olexa, Professor, Food and Resource Economics Department, Florida Cooperative Extension Service, Institute of Food and Agricultural Sciences, University of Florida, Gainesville, FL; Director, Agricultural Law Center, University of Florida, Gainesville, FL; and Chair, Agricultural Law Committee of The Florida Bar. Luke D'Isernia, former student (graduated cum laude in 2005), Levin College of Law, University of Florida, Gainesville, FL. Laura Minton, Attorney, Dean, Mead, Egerton, Bloodworth, Capouano, and Bozarth, Orlando, FL. Dulcy Miller, attorney, Foley and Lardner, LLP, Orlando, FL. Sarah Corbett, Attorney, Florida Second District Court of Appeal, Lakeland, FL.

The Institute of Food and Agricultural Sciences (IFAS) is an Equal Opportunity Institution authorized to provide research, educational information and other services only to individuals and institutions that function with non-discrimination with respect to race, creed, color, religion, age, disability, sex, sexual orientation, marital status, national origin, political opinions or affiliations. U.S. Department of Agriculture, Cooperative Extension Service, University of Florida, IFAS, Florida A. \& M. University Cooperative Extension Program, and Boards of County Commissioners Cooperating. Larry Arrington, Dean 


\section{What Does MSSW Include?}

The scope of the statutes and rules governing surface water management extends basically to the construction, operation, or alteration of any "stormwater management system, dam, impoundment, reservoir, or appurtenant work." The statutory definitions of these terms generally amount to a capability to collectively regulate virtually every type of artificial or natural structure or construction that can be used to connect to, draw water from, drain water into, or be placed in or across surface water. In essence, they include all structures and constructions that can have an effect on surface water. These include:

- Dredging.

- Filling.

- Activities that create canals, ditches, culverts, impoundments, fill roads, buildings and other impervious surfaces.

\section{What Are the Exemptions?}

In order to avoid putting unduly burdensome permitting requirements on farmers, the statute contains a qualified exception. People engaged in the occupation of agriculture, silviculture, floriculture, or horticulture may alter any tract of land without a MSSW permit so long as the practices are normal occupational activities whose sole or predominant purpose is not to obstruct or impound surface water. These "activities" include:

- Site preparation, clearing, fencing, or contouring to prevent soil erosion.

- Soil preparation, plowing, planting, or harvesting.

The exemption is qualified in that the impoundment or obstruction of surface waters may not be the chief purpose of the alteration. Construction or maintenance performed on dikes, dams, or levees in an agricultural closed system will be exempt from MSSW permitting requirements. (Closed system means a self-contained irrigation system used in farming that does not discharge off-site.) Nonetheless, these works must still comply with generally accepted engineering standards and, where the engineering practice is regulated by the state, this might require proper certification of the project and strict adherence with the original plans.

It is always wise to consult with the specific district when attempting to determine if a proposed activity is exempt because a written notice from the DEP or WMD is sometimes required.

\section{What Permits Are Required?}

Certain WMDs rely on the "threshold" concept to determine when a permit is required. For example, once a certain quantity of water is impounded by an activity or a certain size project is proposed, the WMD will require a permit unless the activity is somehow exempt. Although statutory exemptions apply in all five WMDs, permitting thresholds and exemptions adopted by rule will vary from district to district. Water quality and quantity considerations, as well as general environmental concerns, will be addressed in the MSSW permit application process.

As with other types of permits, revocation or modification of the MSSW permit may occur if the permit conditions or the statutory mandates are not met.

\section{What Must Be Shown to Be Eligible for a MSSW Permit?}

At the most basic level, the applicant must show that what is being planned will not be harmful to the water resources and that the planned activity will not be inconsistent with the objectives of the WMD. In other words, the planned activity cannot be against the public interest.

If the planned activity will significantly degrade the water quality, the applicant can still obtain a permit. The applicant must show that the planned activity will be clearly in the public interest. In determining whether a planned activity is contrary to public interest, or is clearly in the public interest, there are seven basic criteria that are balanced as follows:

1. Whether the activity will adversely affect the public health, safety, welfare, or the property of others. 
2. Whether the activity will adversely affect fish and wildlife conservation, including threatened and endangered species and their habitat.

3. Whether the activity will adversely affect navigation or the flow of water, or cause erosion.

4. Whether the activity will adversely affect fishing or recreational values or marine productivity in the area of the activity.

5. Whether the activity is permanent or temporary in nature.

6. Whether the activity will adversely affect or will enhance significant historical and archaeological resources.

7. Whether the current condition and value of activities occurring in the area will be affected by the planned activity.

If the applicant has trouble meeting the criteria of the WMD, the applicant can still get a permit through mitigation.

\section{What Is Mitigation and Mitigation Banking?}

Mitigation is the creation, maintenance, or restoration of a surface water area in exchange for the degradation of another area. If someone plans an activity that will degrade surface water in the area of activity, then that person might still be able to get a permit. However, that applicant will have to mitigate the damage by creating or restoring another area.

\section{What Are the Penalties?}

Aside from modification and revocation of permits, the WMDs are empowered to impose civil penalties up to $\$ 10,000$ per offense per day for mismanagement of surface water in violation of the statutes or permit conditions. Furthermore, intentional violations of the statute may be a second-degree misdemeanor, giving rise to both imprisonment and heavy fines.

\section{Are Other Permits Required?}

Regardless of whether MSSW permit requirements attach to the surface water management system, other permits may be necessary. For example, consumptive-use permit provisions apply to the taking and discharging of water for filling, replenishing, and maintaining the water level in an agricultural closed system. Also, below-threshold-dike (a dike that exists below the water line) building projects might need a fill permit. Any fill permit requirements would involve wetland considerations and federal regulations (see FE606, Activities in Wetlands and Watersheds).

After permit approval, following certain best management practices (BMP) is an excellent way to help ensure continuing compliance with government regulations. Examples include establishing buffer strips and streamside management zones around a system, maintaining streams and culverts so as not to affect upstream or downstream culverts, and careful construction of access roads.

\section{Source}

Chapter 373, Florida Statutes, Sections 373.403 to 373.459; Title 40, Florida Administrative Code (individual WMD rules)

\section{Contact Information}

Surface Water Management and Storage (FE616, Contact Agencies)

- S-1, Florida Water Management Districts

\section{Acknowledgments}

The authors are indebted to the personnel of both state and federal agencies who provided their time and advice in the preparation of this handbook. The authors are especially indebted to Richard Budell of the Office of Agricultural Water Policy of the Florida Department of Agriculture and Consumer Services for providing funds for the development of this publication. 